\title{
トレニア属の種間交雑親和性と系統分類との関係
}

\author{
宮崎 潔 $^{1,2} \cdot$ 桑山智重子 ${ }^{3} \cdot$ 景山幸二 ${ }^{4} \cdot$ 松本省吾 $^{5} \cdot$ 福井博 $^{3}$ \\ 1 岐皁大学大学院連合農学研究科 501-1193 岐阜県岐阜市柳戸 1-1 \\ 2ントリーフラワーズ株式会社５27-0063＼cjkstart滋賀県東近江市大森町字池谷 863-1 \\ ${ }^{3}$ 岐皁大学応用生物科学部 501-1193 岐阜県岐阜市柳戸 1-1 \\ ${ }^{4}$ 岐皁大学流域圈科学研究センター 501-1193 岐阜県岐阜市柳戸 1-1 \\ ${ }^{5}$ 岐皁大学教育学部 501-1193 岐阜県岐阜市柳戸 1-1
}

\section{Relation between Interspecific Compatibility and Phylogenic Analysis in Torenia}

\author{
Kiyoshi MIYAZAKI ${ }^{1,2}$, Chieko KUWAYAMA ${ }^{3}$, Koji KAGEYAMA ${ }^{4}$, \\ Shogo MATSUMOTO ${ }^{5}$ and Hirokazu FUKUI ${ }^{3}$ \\ ${ }^{1}$ United Graduated School of Agricultural Science, Gifu University, Yanagido, Gifu 501-1193, Japan \\ ${ }^{2}$ Suntory Flowers Ltd., 863-1, Iketani, Omori-cho, Higashiomi, Shiga 527-0063, Japan \\ ${ }^{3}$ Faculty of Applied Biological Sciences, Gifu University, Yanagido, Gifu 501-1193, Japan \\ ${ }^{4}$ River Basin Research Center, Gifu University, Yanagido, Gifu 501-1193, Japan \\ ${ }^{5}$ Faculty of Education, Gifu University, Yanagido, Gifu 501-1193, Japan
}

\begin{abstract}
The Genus Torenia is comprised of 40 species. Horticultural cultivars, however, have the problem of a low genetic diversity, because the cultivars originated from only Torenia fournieri. For the purposes of the enhancement of genetic diversity in this study, we investigated interspecific cluster analysis based on the sequence of the internal transcribed spacers (ITS) of nuclear ribosomal DNA among 8 species of Torenia: T. fournieri (TF), T. glabra (TG), T. asiatica (TA), T. concolor (TC), T. baillonii (TB), T. sp-1 (SP1), T. sp-2 (SP2) and $T$. 'Summer Wave' (T. fournieri $\times T$. sp-1) $(\mathrm{SW})$, and the cross compatibility among each species by diallel cross. From the results of phylogenetic cluster analysis by nrDNA and ITS region sequences, the 8 species were classified into two clades: one consisted of TA, TC and TF, and the other consisted of TG, TB, SP1, SP2 and SW. From the diallel cross results, a high cross compatibility was recognized in the crossing of $\mathrm{TC} \times \mathrm{TG}, \mathrm{TC} \times \mathrm{SP} 2$, $\mathrm{TG} \times \mathrm{TC}, \mathrm{TG} \times \mathrm{SP} 2$ and SP $2 \times \mathrm{TG}$. From the analysis of the form of progenies by these crossings, the progenies by crossing between SP2 and TG, which belonged to the same clade, had a prepotent form of TG, and the progenies by crossing between TC and TG or SP2, which belonged to different clades, had flower form intermediate between parents. Cross compatibility was recognized in the crossing among TG, TB, SP1 and SP2 which belonged to the same clade, because fruit set was recognized at least on their crossings with TB. TF, TA and SW had incompatibilities except for some parts. The progeny by crossing TB and $\mathrm{TF}$ had a clearly different flower shape and color compared with TF.
\end{abstract}

Keywords: Interspecific hybrid, ITS, phylogenetic analysis, Torenia

2006 年 7 月 28 日受付

2006 年 12 月 27 日受理

Corresponding author: Kiyoshi Miyazaki

(UII41936@nifty.com) 


\section{緒言}

トレニア属 (ゴマノハグサ科 ) は東アジアから東南アジア, 南アジアそしてアフリカに分布する 40 種からなる植物属であ り, その耐暑性の強さから世界中で夏の花壇用植物として用 いられている. しかし，トレニア園芸品種の育成には Torenia fournieriのみが関わっており, 品種の遺伝的多様性が 低い問題点を持っている. その一例として花色があり, $T$. fournieri は Petunidin, Cyanidin の存在が確認されているも のの主要色素は Malvidin と Peonidin であるため, トレニア 園芸品種の多くは青から紫にかけての花色が主体となってい る. 花色の多様性を高めるために重イオン照射による花色の 突然変異個体の作出 ${ }^{1)}$ などの試みが行われているものの十 分とはいえない. また花型, 草姿の多様性の向上や耐病性 の付与は今後のトレニア育種の重要な課題であり, Torenia fournieri 以外の野生種の導入が不可欠であると考える.

園芸品種の育種において, 種間交雑による新たな形質の 導入が多くの園芸植物で試みられており, 主要な品目につい てみるとペチュニアでは Petunia axillaris と P. violaceae, パンジーではViola tricolorと V. lutea, V. cornuta, V. altaica, V. calcarata, プリムラ・ポリアンサではPrimula veris と P. elatior, P. vulgaris などが種間交雑親として用 いられ, 多くの園芸品種が育成されている. また, バラでは Rosa foetida との交雑によってカロチノイド系色素の生合成 系が導入され, 黄色品種が育成されたことはよく知られてい $る^{2)}$.

トレニアにおける種間交雑を用いた数少ない育種例として “サマーウェーブ” (サントリーフラワーズ株式会社育成 ) があり, これは胚珠培養を用いて T. fournieri と T. concolor との種間雑種から育成されたものである. しかし, これ以外で は種間交雑による育種事例は報告されておらず, 本属内で の他の組み合わせによる種間交雑を試みることによって, より その遺伝的多様性を広げることが可能となり, 近年の地球環 境の大きな変動に耐えうる耐環境性の向上等トレニアの市場 性をより高めることができると考える.

近年の分子系統学の進歩によって様々な植物種間の類縁 関係が解明され始めている ${ }^{3)}$.これらの研究目的の一つには 植物種の進化の解明があるが, この工学的な手法によって明 らかになった類縁関係を基に種間交雑親和性を推察するこ とが可能となれば, 新たな形質導入を目的とした種間雑種育 成の基礎資料とすることができる. また, これらによる知見を基 に肧珠培養などの生物工学的手法を活用し, 効率よく育種を 進めることが可能となる.

本研究ではトレニア属 8 種を用いて, ITS 領域 (5.8S $n r D N A$ を含む) の塩基配列に基づいて種間の類縁関係を 明らかにすると共に, これらの種間でのダイアレルクロスを行 い, 交雑親和性を調査した.

\section{材料および方法}

\section{1.供 試材料}

本研究で使用したトレニアは, T. fournieri (TF), T. glabra (TG), T. asiatica (TA), T. concolor (TC), T. baillonii (TB), T. sp-1 (SP1), T. sp-2 (SP2), T. 'Summer Wave’ (T. fournieri $\times$ T. sp-1) $(\mathrm{SW})$ を用いた. TF, TG, TA, TCは 中華人民共和国広西大学農学院龍明華教授より譲渡され たものを用いた. SP1 および SP2 は T. concolorとして園芸 店で市販されていたものを用いたが, SP1 および SP2 は $T$. concolor とは明らかに形態が異なっていた. TBは種苗会社よ り種子を購入し栽培したものであり, SW はサントリーフラワー ズ株式会社より提供を受けた. すべての供試植物はサントリー フラワーズ株式会社 (滋賀 )の温室にて栽培した.

\section{DNAの抽出およびPCR増幅と塩基配列の解析}

供試植物の茎端部を採取し, 修正 CTAB 法 ${ }^{4)}$ で DNAを 抽出し, 抽出したDNAの濃度は分光光度計で測定した.

核リボソーム DNAの ITS 領域 (5.8S nrDNAを含 む ) の増幅には Whiteらが設計した ${ }^{5)}$ プライマーITS1 (5’-TCCGTAGGTGAACCTGCGG-3’ ) と ITS4(5’ TCCTCCGCTTATTGATATGC-3’ )を用いた。 供試植 物のなかにはITS1 が適合しなかったものがあり, その 場合には 5’ 側に新たに設計したプライマー (TP) (5’ TCTCCGTAGGTGAACCTGCG-3’ ) を用いた.

PCR 反応として, $95^{\circ} \mathrm{C} 5$ 分, $94^{\circ} \mathrm{C} 30$ 秒, $55^{\circ} \mathrm{C} 30$ 秒, $72^{\circ} \mathrm{C}$ 1 分のサイクルを 40 回繰り返し, 最後に $72{ }^{\circ} \mathrm{Cで} 10$ 分間伸長 反応を行い, 電気泳動後にバンドの有無を確認した.

ITS 領域の PCR 産物の精製には Get pureDNA Kit (Dojindo 社製) を用い, 塩基配列の決定には Big Dye $\mathrm{e}^{\mathrm{TM}}$ Terminater Cycle Seqencing Ready Reaction kit (Applied Biosystems 社製) を用いた. 塩基配列の解析において 多型が見られたため, Ligation kit (Takara 社製)を用い て PCR 産物を pT7 T-Vector (Novagen 社製) にクローニ ングし, プライマーM13 forward と M13 reverse を用いて 増幅し, PCR 産物を Gene Elute PCR cleaning kit (Sigma Chemical 社製) を用いて精製し, 塩基配列を決定した。

\section{3.系統樹の推 定}

外群として Limosella major (GenBank nos. AJ550585), 比較種として T. baillonii (GenBank nos. AY492122) を用い た. 全供試植物の ITS 領域 (5.8S nrDNAを含む) の塩基 配列のアライメントは multiple seqence alignment program 
CLUSTAL X ver. 1.81 を用いて行い, アライメントギャップは欠 失デー夕として扱った. これらの塩基配列を PAUP ver. $4.0 \beta$ $10^{6}$ を用いて最大節約法により解析した. ブーツストラップは 各ブランチに対し 1000 回反復し ${ }^{7)}$, 推定系統樹の再現確率 を求めた。

\section{4.種間交雑における交雑親和性の検定}

交雑はダイアレルクロスで実施した. 交配前に自家受粉を防 ぐためにすべての花で除雄を行った，また，自家和合性を確 認するために自家受粉を行った. 播種後, 成育がみられた個 体については, 温室内での葉長, 葉幅, 花径, 花色を調查し た.

\section{結果}

\section{1.塩 基 配列の解析}

プライマーITS1 と ITS4を用いて核リボソーム DNA の ITS 領域 (5.8 S nrDNAを含む) を PCR 増幅した結果, TF, TC, TA, TG, SW, SP2について増幅が確認されたが, SP1，TB では増幅されなかった (第 1 図). SP1 と いてプライマーITS1 との不適合が推定できたことから, PCR による増幅が確認できた供試植物について塩基配列を決定 し, これらに共通する塩基配列を基に 5 側に新たなプライ マーTPを設計した. SP1とTBについて, TPとITS4を用 いて再び PCRによるDNA の増幅を行った結果, 両個体とも 550 から $580 \mathrm{bp}$ 付近にバンドが検出された.

供試した 8 植物について PCR 産物の塩基配列を決定し, これらが ITS 領域 (5.8 S nrDNAを含む) の DNA であるか を同定するために, DDBJ より入手したT. baillonii の ITS 領域のデー夕を用いて $18 \mathrm{~S}, 5.8 \mathrm{~S}$ の相同性を見た. $18 \mathrm{~S}$ の 一部, $5.8 \mathrm{~S}$ 領域についてはほぼすべてが一致し, 得られた DNA 産物は ITS 領域 (5.8 S nrDNA を含む) であると判断 した.

PCR によって得られた ITS 領域 (5.8S nrDNAを含む) の DNA 断片の全長は供試植物によって異なっており, DNA 長 は 466〜 543 bp であった. これらの DNA 長はT. baillonii や L. major と比較すると明らかに短かった (第 1 表). ITS1 領域の DNA 長についてみると, 供試 8 植物では 108 ～ 186 bp であったにの対して, T. baillonii とL. major では 229 bp と $211 \mathrm{bp}$ と差がみられ, 最も DNA 長が短かった TA は T. baillonii の半分以下で, 両者間に $121 \mathrm{bp}$ の差が認めら れた. 同様にITS2 領域においても，供試 8 植物が 153 $195 \mathrm{bp}$ であったにの対して, T. baillonii とL. major は 232 bp, $225 \mathrm{bp}$ と大きく, 最も小さい TG と T. baillonii との間に は $79 \mathrm{bp}$ の差がみられた. しかし, $5.8 \mathrm{~S}$ では供試 8 植物と $T$. baillonii およびL. major との間に差はみられず $161 〜 163$ bpであった.

供試植物と T. baillonii および L. major のアライメント後の ITS 領域の全長は $649 \mathrm{bp}$ であった (第 2 図 ). 挿入・欠失 は ITS1, ITS2 領域で多く, 特に 1 ６5 bp, $601 〜 649$ bp で多くの挿入・欠失がみられた. $5.8 \mathrm{~S}$ 領域では相同性が著 しく高く $67 \%$ の塩基が一致した.

塩基配列の解析において多型が見られたものについてク ローニングを行い，各々のクローンについて塩基配列を決定し た. TF では 4 個のクローンが得られ, 2 塩基 $(436,482$ bp) で異なったものの, その他は同じであった. TA は 5 個のク

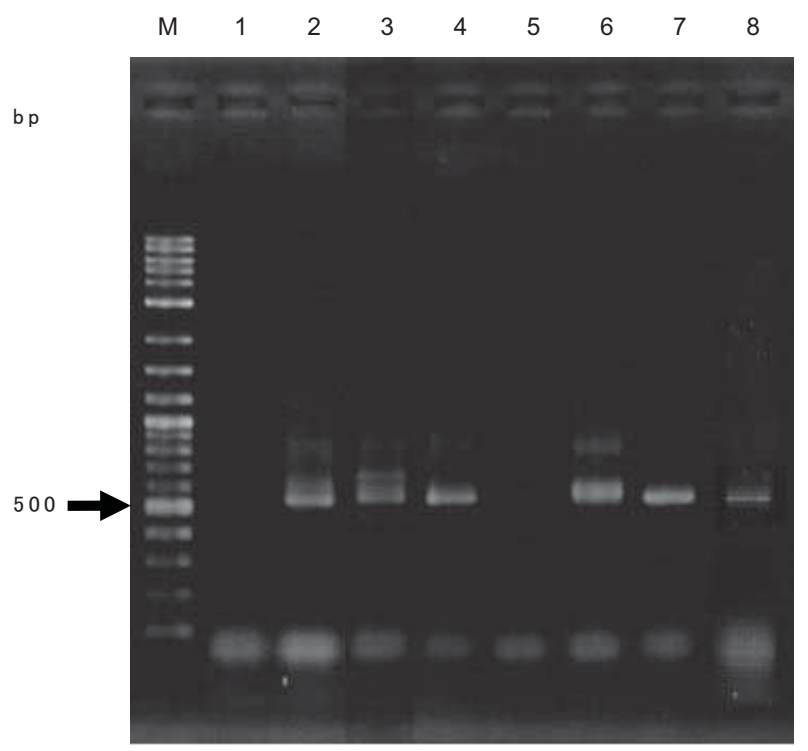

第 1 図 プライマーITS1 とITS4 によるトレニア属 8 植物の核 リボソーム DNA の ITS 領域の PCR 増幅

Fig. 1 Results of PCR amplification in the ITS region of nrDNA of 8 Torenia species using the ITS1 and ITS4 primers.

$\begin{array}{lll}\text { M: } 100 \mathrm{bp} \text { ladder } & \text { 1: TB } & \text { 2: TA } \\ \text { 3: TG } & \text { 4: SP2 } & \text { 5: SP1 } \\ \text { 6: TF } & \text { 7: TC } & \text { 8:SW }\end{array}$

第 1 表 供試したトレニア属 8 種, Torenia baillonii, Limosella major の ITS 領域の長さ

Table 1 Length of the ITS region in 8 Torenia species, Torenia baillonii and Limosella major.

\begin{tabular}{lcccc}
\hline \hline & $\begin{array}{r}\text { ITS1 } \\
(\mathrm{bp})\end{array}$ & $\begin{array}{c}5.8 \mathrm{~S} \\
(\mathrm{bp})\end{array}$ & $\begin{array}{c}\text { ITS2 } \\
(\mathrm{bp})\end{array}$ & $\begin{array}{c}\text { 全ITS領域 } \\
(\mathrm{bp})\end{array}$ \\
\hline $\mathrm{TF}$ & 161 & 161 & 163 & 485 \\
$\mathrm{TC}$ & 186 & 162 & 195 & 543 \\
$\mathrm{TA}$ & 108 & 162 & 183 & 453 \\
$\mathrm{TG}$ & 151 & 162 & 153 & 466 \\
$\mathrm{~TB}$ & 151 & 162 & 153 & 466 \\
$\mathrm{SP1}$ & 151 & 162 & 153 & 466 \\
$\mathrm{SP2}$ & 151 & 162 & 153 & 466 \\
SW & 156 & 162 & 154 & 472 \\
\hline Torenia baillonii & 229 & 163 & 232 & 624 \\
Limosella major & 211 & 163 & 225 & 599 \\
\hline
\end{tabular}




\begin{tabular}{|c|c|c|c|c|c|}
\hline 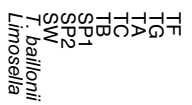 & 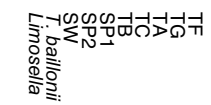 & 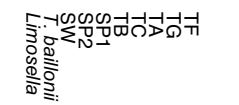 & 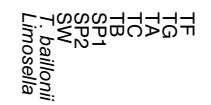 & 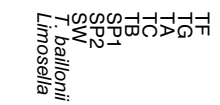 & 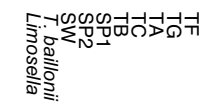 \\
\hline 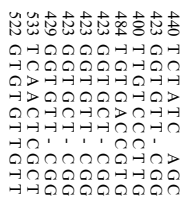 & 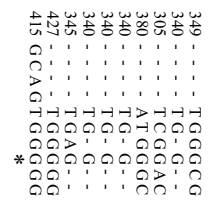 & 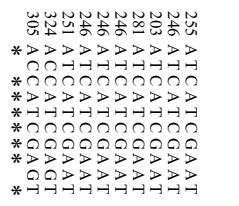 & 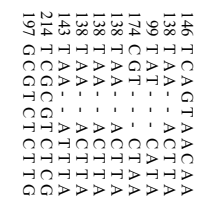 & 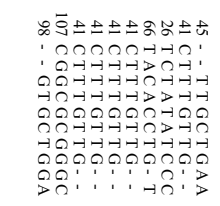 & 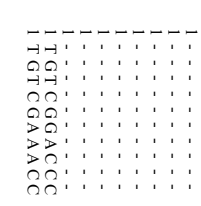 \\
\hline 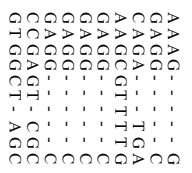 & 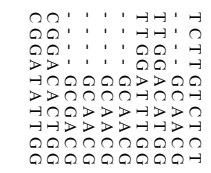 & 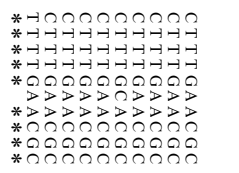 & 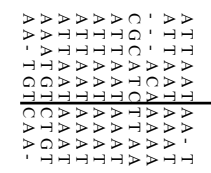 & 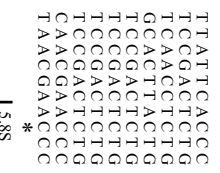 & 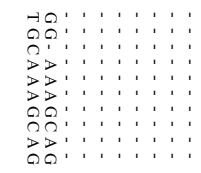 \\
\hline 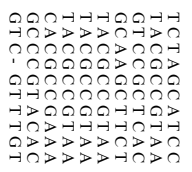 & 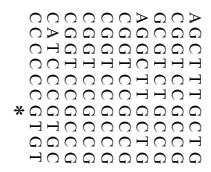 & 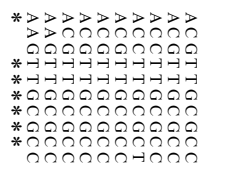 & 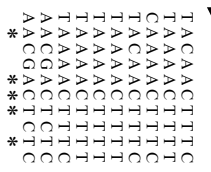 & 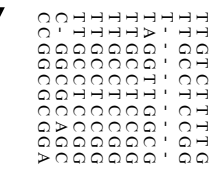 & 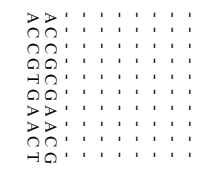 \\
\hline 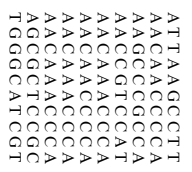 & 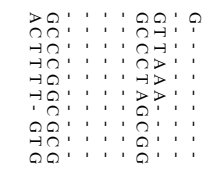 & 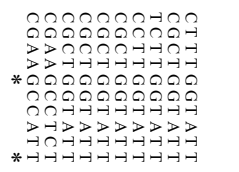 & 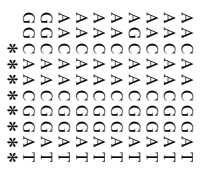 & 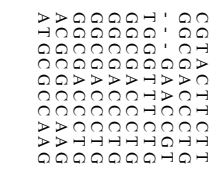 & 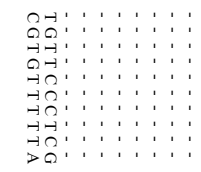 \\
\hline 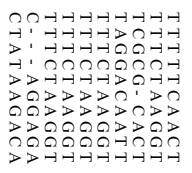 & 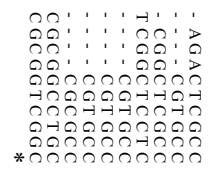 & 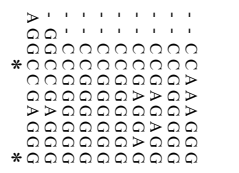 & 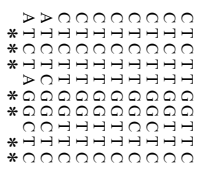 & 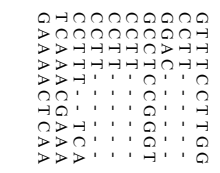 & $\begin{array}{l}>\Omega \\
>\end{array}$ \\
\hline 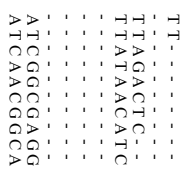 & 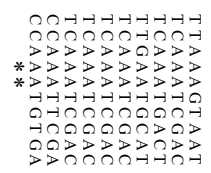 & 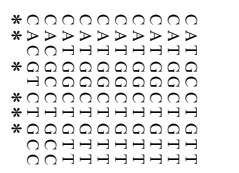 & 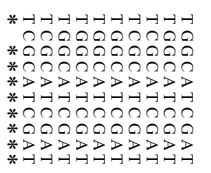 & 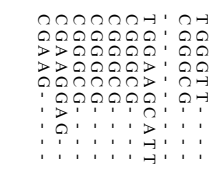 & 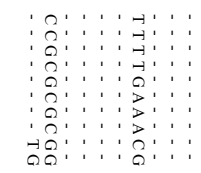 \\
\hline 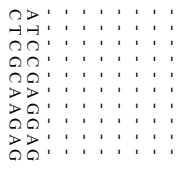 & 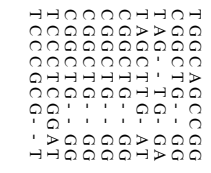 & 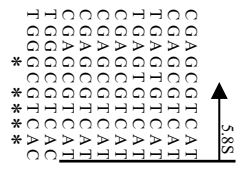 & 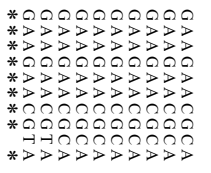 & 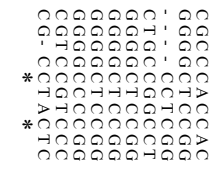 & 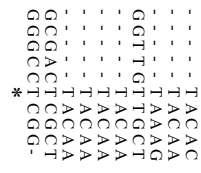 \\
\hline 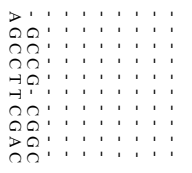 & 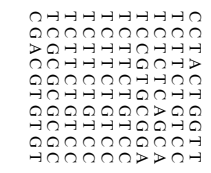 & 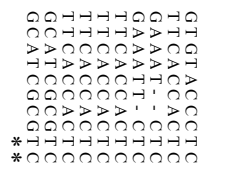 & 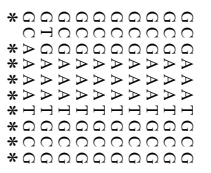 & 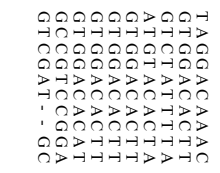 & 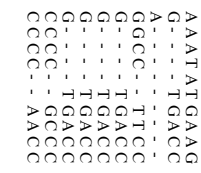 \\
\hline 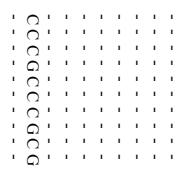 & 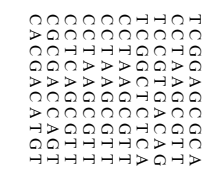 & 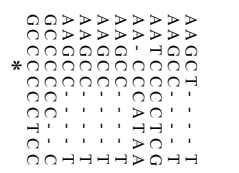 & 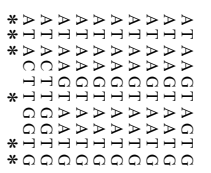 & 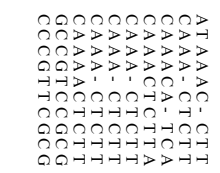 & 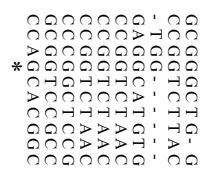 \\
\hline \multirow[t]{2}{*}{ 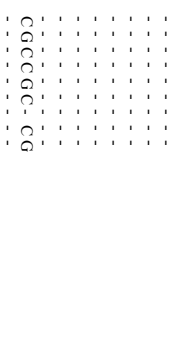 } & 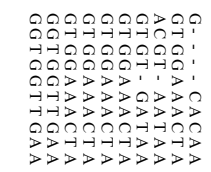 & 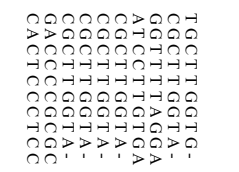 & 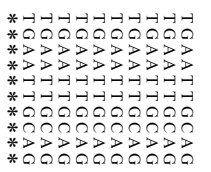 & 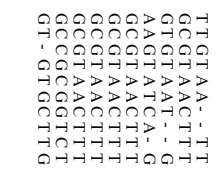 & 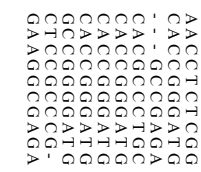 \\
\hline & 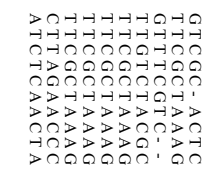 & 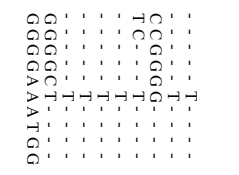 & 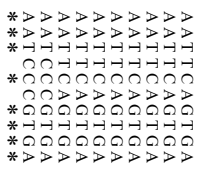 & 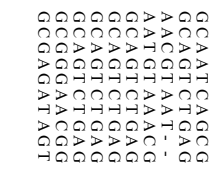 & 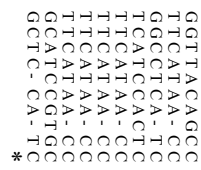 \\
\hline
\end{tabular}

左端の数字はその行の開始の塩基番号を示す．

*部分は全種において同一であることを示す。

矢印は $5.8 \mathrm{~S}$ 領域を現す.

第 2 図 トレニア属 8 植物と T. baillonii および L. major の ITS 領域のアライメント後の塩基配列

Fig. 2 Nucleotide sequence of the ITS region in 8 Torenia species, T. baillonii and Limosella major. 
第 2 表 トレニア属 8 植物間のダイアレルクロスによる交雑 親和性

Table 2 Cross compatibility between 8 Torenia species on diallel cross.

\begin{tabular}{|c|c|c|c|c|c|c|c|c|c|}
\hline & \multicolumn{8}{|c|}{ 花粉親 } \\
\hline & & $\mathrm{TF}$ & $\mathrm{TC}$ & TA & $\mathrm{TG}$ & $\mathrm{TB}$ & SP1 & SP2 & SW \\
\hline \multirow{8}{*}{ 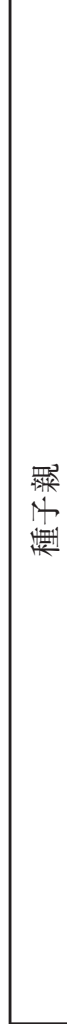 } & $\mathrm{TF}$ & $\bigcirc$ & A2 & A2 & $\mathrm{A} 2$ & $\begin{array}{l}\text { A1 } \\
\text { B1 } \\
\text { C1 } \\
\text { D2 }\end{array}$ & A2 & A2 & $\mathrm{A} 2$ \\
\hline & $\mathrm{TC}$ & $\mathrm{A} 2$ & $\bigcirc$ & $\mathrm{A} 2$ & $\begin{array}{l}\mathrm{A} 1 \\
\mathrm{~B} 1 \\
\mathrm{C} 1 \\
\mathrm{D} 1\end{array}$ & A2 & $\mathrm{A} 2$ & $\begin{array}{l}\text { A1 } \\
\text { B1 } \\
\text { C1 } \\
\text { D1 }\end{array}$ & $\mathrm{A} 2$ \\
\hline & TA & A3 & A3 & 0 & A3 & A3 & $\mathrm{A} 2$ & A3 & $\mathrm{A} 2$ \\
\hline & TG & $\mathrm{A} 2$ & $\begin{array}{l}\mathrm{A} 1 \\
\mathrm{~B} 1 \\
\mathrm{C} 1 \\
\mathrm{D} 1\end{array}$ & $\mathrm{~A} 2$ & 0 & A2 & $\begin{array}{l}\mathrm{A} 1 \\
\mathrm{~B} 1 \\
\mathrm{C} 2\end{array}$ & $\begin{array}{l}\text { A1 } \\
\text { B1 } \\
\text { C1 } \\
\text { D1 }\end{array}$ & $\mathrm{A} 2$ \\
\hline & $\mathrm{TB}$ & $\begin{array}{l}\mathrm{A} 1 \\
\mathrm{~B} 2 \\
\end{array}$ & A2 & A2 & $\begin{array}{l}\mathrm{A} 1 \\
\mathrm{~B} 2\end{array}$ & $\bigcirc$ & $\begin{array}{l}\text { A1 } \\
\text { B2 }\end{array}$ & $\begin{array}{l}\mathrm{A} 1 \\
\mathrm{~B} 2 \\
\end{array}$ & $\mathrm{~A} 2$ \\
\hline & SP1 & $\mathrm{A} 2$ & $\begin{array}{l}\mathrm{A} 1 \\
\mathrm{~B} 1 \\
\mathrm{C} 2\end{array}$ & A2 & $\begin{array}{l}\mathrm{A} 1 \\
\mathrm{~B} 1 \\
\mathrm{C} 2\end{array}$ & $\mathrm{~A} 2$ & $x$ & A2 & $\mathrm{A} 2$ \\
\hline & SP2 & $\mathrm{A} 2$ & A3 & A3 & $\begin{array}{l}\mathrm{A} 1 \\
\mathrm{~B} 1 \\
\mathrm{C} 1 \\
\mathrm{D} 1\end{array}$ & A3 & $\begin{array}{l}\mathrm{A} 1 \\
\mathrm{~B} 2\end{array}$ & $\bigcirc$ & $\mathrm{A} 2$ \\
\hline & SW & $\mathrm{A} 2$ & $\mathrm{~A} 2$ & A2 & $\mathrm{A} 2$ & $\mathrm{~A} 2$ & $\mathrm{~A} 2$ & $\mathrm{~A} 2$ & $\times$ \\
\hline \multicolumn{5}{|c|}{ A1:結実 A2:未結実 } & $\mathrm{A} 3$ & & は発声 & 剘 & 自殖 \\
\hline \multicolumn{5}{|c|}{$\begin{array}{l}\mathrm{D} 1: 80 \% \text { 以上の個体が成育 } \\
\text { : 自殖稔性 }\end{array}$} & $\begin{array}{l}\mathrm{C} 2 \\
\mathrm{D} 2 \\
\times\end{array}$ & $\begin{array}{l}\text { : } 1 \text { 発茅個 } \\
\text { 自殖 }\end{array}$ & $\begin{array}{l}\text { 体が成 } \\
\text { 稔 }\end{array}$ & & \\
\hline
\end{tabular}

ローン (TA-1 〜 5) が得られ, TA-1 〜 3 の塩基配列は同じで あった. TA-4 は TA-1～3 と ITS2 領域では差がみられず, $5.8 \mathrm{~S}$ 領域で 162 塩基のうち 1 塩基が久損し, 5 塩基で異な った. しかし, ITS1 領域では 163 塩基のうち 86 塩基が異な っていた. TA-5 は TA-4 と ITS1 および $5.8 \mathrm{~S}$ 領域の塩基配 列が同じであったものの, ITS2 領域では 110 塩基が異なって いた. TB で得られたクローンの塩基配列は相同であった.

\section{2.系 統 樹}

供試した 8 植物と T. baillonii について, L. major を外群 として用い, 最大節約法によって推定した系統樹を第 3 図に 示した. 最大節約系統樹の長さは 584 であり, CI $=0.8818$, $\mathrm{RI}=0.7076$ であった.

本研究で供試した Torenia 属 7 種および 1 品種は 2 つの クレードを形成し, 1 つは TA, TC, TF からなり, 他のクレード は TG, TB, SP1，SP2 および SW で構成された.

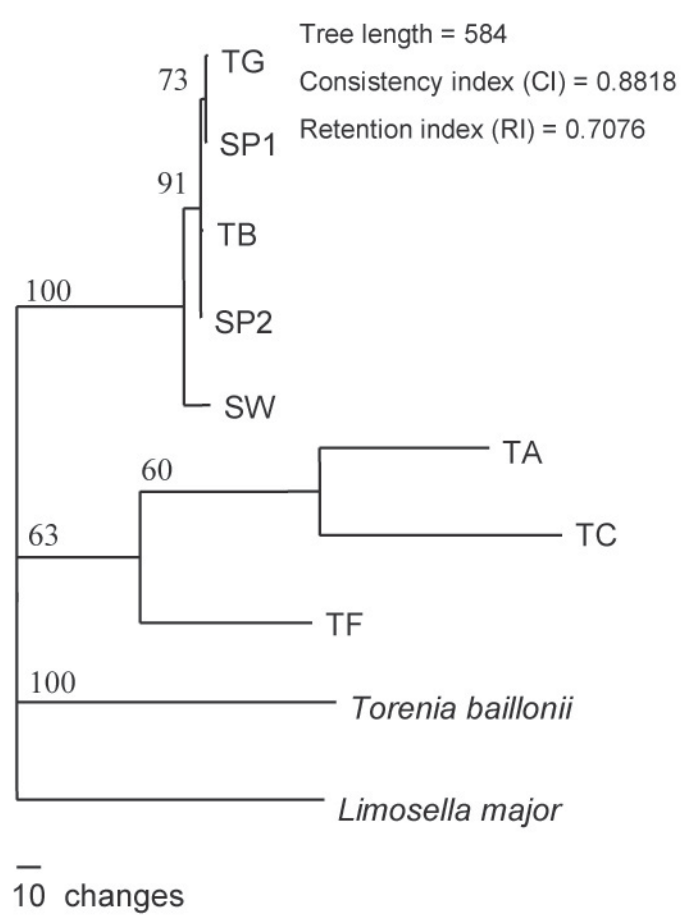

第 3 図 L. majorを外群としたトレニア属 8 植物と $T$. baillonii の系統関係

Fig. 3 Phylogenetic tree constructed from the ITS region sequence data using the maximum persimony method. The bootstrap confidence values (\%) are indicated on the branches.

\section{3.交雑親和性と系統樹との関係}

供試した 8 植物についてダイアレルクロスを行い, 交雑親 和性についての判別結果を第 2 表に示した. 交雑親和性の 判定にあたり, 結実の有無を基準に用いた. Torenia 属植物 の種子は極めて微細であり, 形成した種子の稔性を外観から 判定することが困難であったため，結実した個体については 得られた種子を播種し, その発芽の有無で種子稔性を判定 した. また, 発芽した個体について, その形態から交雑個体 と自殖個体の判別を行った.

交雑個体が得られ，高い交雑親和性が認められたのは $\mathrm{TC} \times \mathrm{TG}, \mathrm{TC} \times \mathrm{SP} 2, \mathrm{TG} \times \mathrm{TC}, \mathrm{TG} \times \mathrm{SP} 2, \mathrm{SP} 2 \times \mathrm{TG}$ の 組み合わせであった. 第 3 図の系統樹との比較から TG と SP2 は同一クレードに属し, 両種の正逆交雑で交雑個体が得 られたことから，交雑親和性の観点からも近縁の種であると 推定できた. 同様に TC と TG は正逆交雑で交雑個体が得ら れたが, 系統樹においては別のクレードに属しており,さらに

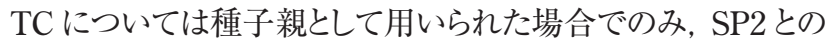
交雑組み合わせで交雑個体が得られた.

系統樹に氺いて TG や SP2 と同一クレードに属したSP1に ついてみると, TG との正逆交雑において交雑個体は得られ なかったものの, 発芽能力を持つ稔性種子が得られた. 同様 


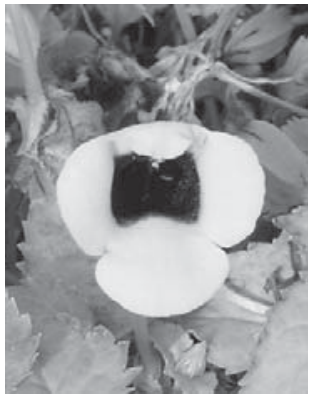

T B

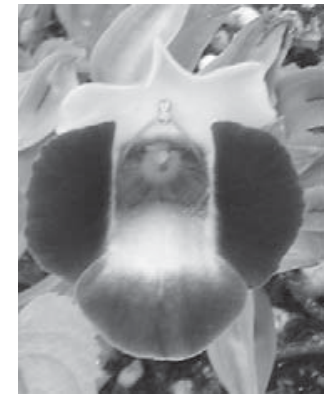

$\mathrm{TB} \times \mathrm{TF}$ の 交雑 個 体

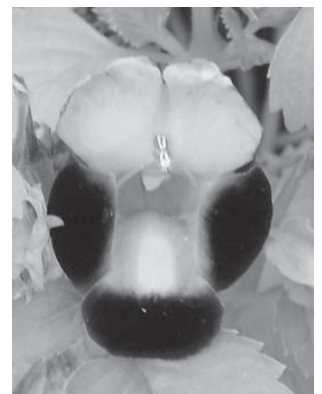

T F

第 4 図 $\mathrm{TB}$ と $\mathrm{TF}$ との交雑個体の花の形態

Fig. 4 Picture showing the flower characters of TB, TF and their hybrid.

第 3 表 $\mathrm{TC} \times \mathrm{TG}, \mathrm{TC} \times \mathrm{SP} 2, \mathrm{TG} \times \mathrm{TC}, \mathrm{TG} \times \mathrm{SP} 2$, $\mathrm{SP} 2 \times \mathrm{TG}$ の交雑で得られた交雑個体の形態

Table 3 Characters of hybrids from TC $\times$ TG, TC $\times$ $\mathrm{SP} 2, \mathrm{TG} \times \mathrm{TC}, \mathrm{TG} \times \mathrm{SP} 2$ and $\mathrm{SP} 2 \times \mathrm{TG}$.

\begin{tabular}{|c|c|c|c|c|}
\hline & & SP2 & $\mathrm{TG}$ & $\mathrm{TC}$ \\
\hline \multicolumn{2}{|c|}{ 花径 (cm) } & $2.6 \pm 0.06$ & $2.7 \pm 0.15$ & $1.9 \pm 0.10$ \\
\hline $\mathrm{SP} 2 \times \mathrm{TG}$ & $2.8 \pm 0.07$ & $* *$ & NS & - \\
\hline $\mathrm{TG} \times \mathrm{SP} 2$ & $2.7 \pm 0.12$ & $*$ & NS & - \\
\hline $\mathrm{TC} \times \mathrm{TG}$ & $2.3 \pm 0.09$ & - & $* *$ & $* *$ \\
\hline $\mathrm{TG} \times \mathrm{TC}$ & $2.3 \pm 0.09$ & - & $* *$ & $* *$ \\
\hline $\mathrm{TC} \times \mathrm{SP} 2$ & $2.3 \pm 0.05$ & $* *$ & - & $* *$ \\
\hline \multicolumn{2}{|c|}{ 葉長／葉幅比 } & $0.84 \pm 0.08$ & $0.75 \pm 0.05$ & $0.71 \pm 0.12$ \\
\hline $\mathrm{SP} 2 \times \mathrm{TG}$ & $0.72 \pm 0.08$ & $* *$ & NS & - \\
\hline $\mathrm{TG} \times \mathrm{SP} 2$ & $0.79 \pm 0.04$ & NS & NS & - \\
\hline $\mathrm{TC} \times \mathrm{TG}$ & $0.85 \pm 0.06$ & - & $* *$ & $* *$ \\
\hline $\mathrm{TG} \times \mathrm{TC}$ & $0.83 \pm 0.06$ & - & $* *$ & $*$ \\
\hline $\mathrm{TC} \times \mathrm{SP} 2$ & $0.86 \pm 0.07$ & NS & - & $* *$ \\
\hline \multicolumn{2}{|c|}{ 節間長(cm) } & $2.9 \pm 0.41$ & $3.9 \pm 0.37$ & $3.8 \pm 0.37$ \\
\hline $\mathrm{SP} 2 \times \mathrm{TG}$ & $4.0 \pm 0.70$ & $* *$ & NS & - \\
\hline $\mathrm{TG} \times \mathrm{SP} 2$ & $4.2 \pm 0.59$ & $* *$ & NS & - \\
\hline $\mathrm{TC} \times \mathrm{TG}$ & $4.4 \pm 0.54$ & - & $*$ & $*$ \\
\hline $\mathrm{TG} \times \mathrm{TC}$ & $3.7 \pm 0.53$ & - & NS & NS \\
\hline $\mathrm{TC} \times \mathrm{SP} 2$ & $3.9 \pm 0.38$ & $* *$ & - & NS \\
\hline
\end{tabular}

に, SP1 は別のクレードに属する TC との間でも稔性種子の 形成が認められ，同じクレードに属する TG が TC と交雑親 和性が高かったこととも一致した. また SP1を花粉親として用 いた場合には，TG，TB，SP2 との交雑組み合わせにおいて 発芽は見られなかったものの結実が確認され，系統樹におい て同一クレードに属する種間での交雑親和性が推定された.
$\mathrm{TB}$ についてみると, 種子親として用いた場合には同一ク レードに属する TG, SP1, SP2 との間で稔性のある種子は得 られなかったものの結実が認められ，さらに別のクレードに属 する TF との交雑でも結実が認められた. また, 花粉親として 用いた場合には $\mathrm{TF}$ との間で菊池らの報告 ${ }^{8)}$ にあるように交 雑個体が 1 個体得られた。 この交雑個体は, 第 4 図に示す ように, 花形や花色において両親の中間の形質を示した.

$\mathrm{TF}$ は，他の種との正逆交雑において，TB 以外では交雑 親和性を示さなかった．また， TA および $\mathrm{SW}$ はいずれも他の 種とも交雑親和性を示さなかった。

ダイアレルクロスによって交雑個体が多数得られた TC $\times$ $\mathrm{TG}, \mathrm{TC} \times \mathrm{SP} 2, \mathrm{TG} \times \mathrm{TC}, \mathrm{TG} \times \mathrm{SP} 2, \mathrm{SP} 2 \times \mathrm{TG}$ の交雑個 体について, 両親との間での形態的差異を検討したものが第 3 表である.

$\mathrm{SP} 2 \times \mathrm{TG}$ および $\mathrm{TG} \times \mathrm{SP} 2$ は花径, 葉長 / 葉幅比, 節 間長共に花粉親の $\mathrm{TG}$ に近い形態を示した. $\mathrm{TC} \times \mathrm{TG}$ およ び TG $\times \mathrm{TC}$ の花形は両親の中間の形態を示し，葉は丸み を带びた形状を示した. 節間については TC $\times \mathrm{TG} て ゙$ 長くなつ た. $\mathrm{TC} \times \mathrm{SP} 2$ の花形は両親の中間の形態を示したが，それ 以外の形態は TCに近かった

\section{考察}

供試した 8 植物と T. baillonii の ITS 領域 (5.8 S nr DNA を含む）の塩基配列を比較すると, $5.8 \mathrm{~S}$ はほとんど変異がみ られなかったが, ITS1 とITS2 領域では塩基置換，挿入・欠 失が多くみられた，従って，系統樹での分離はITS1 と ITS2 領域の変異が関与しており, 他の植物の種間変異と類似して いた ${ }^{9)}$.

供試した植物は, 系統樹において TA, TC, TF のクレード と TG, TB, SP1，SP2, SW のクレードに大別できた. TA, 
TC, TF は TA, TCと TFに分けられ, 同様に $\mathrm{TG}, \mathrm{TB}$, SP1，SP2, SW のクレードはさらに TG, TB, SP1，SP2 と SW に分けられた。

TA と TC は, ITS 領域 (5.8 S nr DNAを含む) の塩基配 列からみると同一クレードに属し，両種が近縁種であると考え られたが, 交雑試験の結果では結実すら確認できなかった. 同様に TA や TC と比較的近縁とされた TF についても両種 との間で交雑親和性が全〈認められなかった.この原因とし て TAの交雑不稔性が関係していると考える. TA は自殖稔 性を持っていたものの, すべての交雑で結害が認められなか った. また, TC の染色体数が $2 \mathrm{n}=16$ であるとの報告 ${ }^{10)}$ や $\mathrm{TF}$ の染色体数が $2 \mathrm{n}=18$ であったとの報告 ${ }^{11,12)}$ から, トレニ ア属に異数性の存在が知られており, これが $\mathrm{TC} や \mathrm{TF}$, 染 色体数が未報告である $\mathrm{TA}$ 間の交雑不親和の原因の 1 つで あると推察され，今後染色体数の解明が必要と考えられる。

TG, TB, SP1, SP2, SW のクレードについてみると, TG, TB, SP1, SP2 の 4 種間の塩基の違いは最大でも数塩基の 差異しかなく, 極めて類縁関係が高いと推定できた. なかで も TG と SP1 および SP2 との間では著しく高い交雑親和性が 認められ，TG と SP2 との間では正逆交雑で交雑個体が得ら れた. TG, SP1，SP2の染色体数も未だ報告されていないが 同数であることが推察できる. これに対して TB は TG, SP1, SP2 のいずれとも交雑親和性が低かった.

SP1 とSP2 は園芸店でT. concolor として市販されていた ものであったが, 形態的にも明らかに TC とは異なっており, 形態的に T. concolor と判断できた本研究で供試した TC と明らかに異なるクレードに属していたことから，両種は $T$. concolor とは別種と推定された. また SP1と SP2 を比較する と, 両者の塩基配列は $555 \mathrm{bp}$ での 1 塩基の差異であった が, 茎葉や節間長は明らかに異なり, 加えて SP1では花芽が 側生するのに対して SP2 では頂生することから，両者が別種 である可能性が高いと判断した。

TB は T. baillonii として種苗会社より種子を購入して栽培 した黄色花を持つ個体であったが, DDBJに掲載されていた T. baillonii の塩基配列とは明らかに異なっており, 別種であ ると推定された，TB が近縁である TG, SP1，SP2 との交雑 親和性が低かった原因として, T. fournieri と T. baillonii の 染色体数が同数である ${ }^{13)}$ ために $\mathrm{TA}, \mathrm{TC}, \mathrm{TF}$ 間での交雑 不稔と同様に染色体数の差異が関与している可能性が推察 できた. 菊池らの報告 ${ }^{8)}$ では, 動原体の特異反復配列から T. baillonii と T. fournieri, T.concolor, $\mathrm{SW}$ とは異なるグル 一プに属すると述べられており，系統樹上で異なるクレードに 分けられた結果と一致する。

$\mathrm{TF}$ と $\mathrm{TB}$ との交雑で得られた交雑個体は，これまでに 品種登録されているトレニア品種とは明らかに異なる花色
を示した. 現在のトレニア品種の親として用いられている $T$. fournieri の花色素は Malvidin, Peonidin を主としたアントシ アニン類で構成されていることが明らかとなっており ${ }^{1)}$, TB の 黄色の花色はこれらのアントシアニン類ではなくフラボン類で 構成されていると推定できる. アントシアニン類で構成される品 種に対してフラボン類を持つ野生種を交配した例としてバラの 事例があり ${ }^{2)}$, Rosa foetida との交雑によって黄色の花色を持 つ品種群が形成されている. 今後, この交雑個体を育種親と して用いることで新たな花色を持つトレニア品種群を育成する ことが可能となると考える.

SW は TG, TB, SP1，SP2 と同一クレードに属したにも関わ らず交雑個体はまったく得られなかった。このことは, SW が T. fournieri と SP1 の交雑個体であり, 自殖稔性が認められ なかったことからも明らかなように, 種間雑種の特性として稔 性が著しく低いことが原因であると考えられる. また，SW が T. fournieri と SP1 の交雑個体であることは，系統樹におい て SW が TF と SP1の中間に位置していることと一致し, 系 統樹の信頼性が証明された。

本研究で多数の交雑個体が得られた組み合わせにおい て，両親の形質との関係をみた結果，近縁と推定される SP2 と TG との交雑個体ではその形質が TGに近くなり, TGの 形質が優性に発現されるものと考える.これに対して，異なる クレードに分類された TC と TG および SP2 との組み合わせ では, 花形が両親の中間の形質を示した. 今後これらの交雑 個体を育種親として用いた交雑を行うことで, 新たなトレニア 品種作出の可能性が推察できた。

以上のことから本研究結果を総合的に判断すると, 系統樹 から交雑親和性を単純に推定することは難しいと判断できた. トレニア属のように種間に異数性が存在する植物属において は, 染色体数の情報も付加して交雑親和性を考慮する必要 があるものと考える. しかし，系統樹から得られた結果は種間 の遠縁関係を明らかにしており，遠縁種の導入による新規形 質の付与を目的とした育種計画の作成に役立てることが可能 である.

トレニア品種の中で T. fournieri と SP1 の種間雑種として 知られる SW は, その育成経過に扔いて未熟胚培養が用い られている. 本研究では交雑後に得られた種子を播種して交 雑親和性を検討したが, 今後は本研究の系統樹で明らかと なった T. fournieri と遠縁種との交雑個体の獲得過程におい て, 未熟胚培養を行うことで新たな品種育成の可能性を探っ ていきたい。

\section{摘 要}

トレニア属は 40 種からなる植物属であるが, 園芸品種の育 
成には Torenia fournieri のみが関わっており, 品種の遺伝 的多様性が低い問題点を持っている. 本研究では, トレニア 品種の遺伝的多㥞性を拡大することを目的とし, T. fournieri (TF), T. glabra (TG), T. asiatica (TA), T. concolor (TC), T. baillonii (TB), T. sp-1 (SP1), T. sp-2 (SP2), T. 'Summer Wave' (T. fournieri $\times T$. sp-1)(SW) を用い, 核リボソーム DNAの ITS 領域 (5.8S nr DNA を含む) の塩基配列に基 づいて種間の類縁関係を明らかにすると共に, これらの種間 でのダイアレルクロスを行い交雑親和性を調査した. 核リボ ソーム DNA の ITS 領域の全塩基配列から系統樹を作成し た結果，TA，TC，TF からなるクレードと TG，TB， SP1，SP2 および SW で構成されるクレードにわけられた.ダイアレルク ロスの結果, $\mathrm{TC} \times \mathrm{TG}, \mathrm{TC} \times \mathrm{SP} 2, \mathrm{TG} \times \mathrm{TC}, \mathrm{TG} \times \mathrm{SP} 2$, $\mathrm{SP} 2 \times \mathrm{TG}$ の組み合わせで高い交雑親和性が認められた. 同一クレードに属する SP2 と TG との交雑個体では TG の形 質が優性に発現され，異なるクレードに属する TC と TG お よびSP2 との組み合わせでは, 花形が両親の中間の形質を 示した. 同一クレードに属した TG, TB, SP1，SP2 との交雑 に打いても結実や稔性種子の形成が認められ，同一クレード に属する種間での交雑親和性が確認できた. TF, TA およ び SW は一部を除いて他の種と交雑親和性を示さなかった。 $\mathrm{TB} \times \mathrm{TF}$ で 1 個体の交雑個体が得られ，TF とは異なる花形 や花色を持つ交雑個体が得られた。

\section{謝 辞}

本実験を遂行するにあたり, 広西大学農学院龍 明華教 授ならびに于 文進講師には供試材料の提供において多大 な御協力を頂きました. ここに深く感謝いたします.

\section{引用文献}

1) Miyazaki K, Suzuki K, Iwaki K, Kusumi T, Abe T, Yoshida S, Fukui H. Acquirement mutants of the interspecific hybrid of Torenia by irradiation of heavy ion Beams. Plant Biotechnology 33: 163-167. 2006.

2) Wylie AP. The history of garden rose-Part I. J. Roy. Hort. Sci. 79: 555-571. 1954.

3) Matsumoto S, Fukui $\mathrm{H}$, Identification of rose cultivars and clonal plants by random amplified polymorphic DNA. Sci. Hort. 67: 49-54. 1996.

4) Doyle JJ, Doyle JL. A rapid DNA isolation procedure for small quantities of fesh leaf tissue. Phytochem. Bull. 19: 11-15. 1987.

5) White TJ, Bruns T, Lee S, Tayler J. Amplification and direct sequencing of fungal ribosomal RNA genes for phylogenies. PCR Protocols, A Guide to Methods and Applications. San Diego, Academic Press: 315-322. 1990.

6) Swofford DL. PAUP: Phylogenetic Analysis Using Parsimony (and other methods), ver 4.0b10. SinauerAssociates, Sunderland, Massachusetts. 2000.

7) Felsenstein J. Confidence limits on phylogenies: an approach using the bootstrap. Evolution 39: 783-791. 1985.

8) Kikuchi S, Kishi M, Shimizu M, Tsujimoto H. Centromerespecific repetitive sequence from Torenia, a model plant for interspecificfertilization, and wholemount FISH of its interspecific hybrid embryos. Cyotgenet. Genome Res. 109: 228-235. 2005.

9) Matsumoto S, Kouchi M, Fukui H. Phylogenetic analyses of the subgenus Eurosa using the ITS nrDNA sequence. Acta. Hort. 521: 193-202. 2000.

10) Hsu CC. Preliminary chromosome studies on the vascular plants of Taiwan (II). Taiwaniana 14: 11-27. 1968.

11) Straub J. Chromosomenuntersuchungen an polyploiden Blutenpflanzen. I. Die Chromatinmasse bei kunstlich ausgelosten Autopolyploiden. Ber. Deutsch. Bot. Ges. 57: 531-544. 1939.

12) Subramanian D, Pondmudi R. Cytotaxonomical studies of south Indian Scrophulariaceae. Cytologia 52: 529-541. 1987.

13) Kikuchi S, Tanaka H, Shiba T, Mii M, Tsujimoto H. Genome size, karyotype, meiosis and a novel extra chromosome in Torenia fournieri, T. baillonii and their hybrid. Chromosome Res. 14: 665-672. 2006. 